\title{
ANALISIS BREAK EVEN POINT SEBAGAI ALAT PERENCANAAN LABA PADA PERUSAHAAN BROWCYL BROWNIS PISANG KHAS MAKASSAR
}

\author{
Rosida \\ STIE LPI Makassar \\ Rosida93@gmail.com
}

\begin{abstract}
,
This article is the result of a study that analyzes break even point as a profit planning tool at the Makassar Banana Browcyl Brownis company. Located on Jl. A.P. Pettarani Kota Makassar, research using descriptive method based on case studies aims to determine the value of each variable, either one variable or more independent in nature without making a relationship or comparison with other variables. Data processing is done by looking for contribution margin value, break even point and margin of safety. The results of this study indicate that in 2017 the break-even achieved by the company was Rp. 72,070,308.51 and BEP per $\mathrm{kg}$ of Rp. 1.018. In 2018 the break-even point reached by the company was Rp. 69,612,903.23 and BEP per $\mathrm{kg}$ of 2,308. The margin of safety in 2017 to 2018 has increased $83 \%$ to $86 \%$. Sales in 2017 and 2018 have reached the calculated sales target. This research is important because it allows companies to conduct business expansion or increase production in accordance with the company's capacity.
\end{abstract}

Keywords: Contribution Margin, Break Even Point and Margin Of Safety.

\section{PENDAHULUAN / INTRODUCTION}

Perkembangan bisnis yang sangat pesat, menimbulkan persaingan pasar yang cukup ketat. Setiap harinya muncul pelaku bisnis yang mengenalkan produkdengan kreativitas dan inovasi baru sehingga persaingan pasar pun tidak bisa dihindari (Tjiptono dan Chandra, 2012: 1). Jika para pelaku usaha tidak berusaha menjadi diri yang kreatif dan inovatif, usahanya akan tersingkir dari persaingan pasar. Kreatif dalam menjalankan bisnis menjadi salah satu kunci sukses sebuah perusahaan untuk menciptakan produk yang siap bersaing di pasaran.

Setiap perusahaan mempunyai peranan penting dalam perekonomian. Berhasil atau tidaknya suatu usaha dapat dilihat dari kemampuan manajemen dalam melihat kemungkinan dan kesempatan dimasa yang akan datang. Tujuan perusahaan dalam perokonomian yang semakin berkembang adalah untuk memperoleh laba yang semakin besar sesuai dengan pertumbuhan perusahaan. Dengan tujuan tersebut perusahaan harus merencanakan dan menggunakan sumber daya yang ada secara optimal agar tercapainya tujuan perusahaan (Ichsandy, 2018: 1).

Keberhasilan suatu perusahaan umumnya dicerminkan oleh kemampuan manajemen di dalam melihat peluang dan kemungkinan di masa yang akan datang, baik untuk jangka pendek maupun jangka panjang. Untuk itu manajemen harus dapat merencanakan segalanya untuk masa yang akan datang agar kemungkinan dan peluang yang diperkirakan dapat dicapai (The dan Sugiono, 2015: 78). 
Keberhasilan suatu manajemen dinilai dan diukur dari laba yang diperoleh perusahaan. Perencanaan merupakan hal yang sangat penting karena akan mempengaruhi kelancaran dan keberhasilan perusahaan dalam mencapai tujuannya. Serta dapat menyadari segala resiko dan kemungkinan buruk yang akan terjadi sewaktu-waktu. Manajemen harus memiliki kemampuan yang tinggi agar dalam menghadapi resiko tersebut dapat terselesaikan dengan baik, dengan membuat perencanaan, manajemen telah memiliki alat untuk memprediksi penjualan dan target laba yang akan dibuat oleh perusahaan.

Supaya dapat meningkatkan laba, maka perlu membuat strategi dan perencanaan untuk masa mendatang. Di antaranya yang dapat dilakukan dalam usaha meningkatkan laba adalah: 1 . Menekan biaya operasional dan mempertahankan harga jual dengan volume penjualan yang sama. 2 . Meningkatkan volume penjualan 3. Meningkatkan harga jual sesuai dengan laba yang dikehendaki (Munawaroh, 2016: 2).

Salah satu alat pengukur perencanaan laba bagi perusahaan ialah dengan menggunakan Analisis Biaya Volume laba (BVL) atau Cost Volume Profit Analysis. Analisis biaya, volume dan laba merupakan elemen pokok dalam penyusunan laporan laba rugi pada suatu perusahaan. Analisis biaya volume dan laba adalah pemeriksaan bagaimana jumlah pendapatan dan jumlah biaya berubah seiring dengan perubahan volume penjualan. Pemhaman mengenai konsep biaya, volume dan laba dapat digunakan oleh manajemen sebagai dasar untuk merencanaan komposisi tingkat biaya, volume dan laba yang menguntungkan (Astuti 2014: 78).

Analisis biaya volume laba akan memudahkan perusahaan dalam menentukan target pendapatan dan jumlah biaya yang dikeluarkan dalam upaya mencapai laba yang telah ditentukan tersebut. Menurut Hansen dan Mowen (2000: 457) mengemukakan bahwa "analisis biaya volume laba memfokuskan pada harga, pendapatan, volume, biaya, laba dan kombinasi penjualan". Analisis ini dapat digunakan untuk menentukan volume penjualan atau pendapatan yang diperlukan supaya impas atau mencapai target laba. Perubahan pada pola biaya tetap dan variabel mempengaruhi tingkat keuntungan perusahaan. Perusahaan dapat menggunakan analisis CVP untuk melihat bagaimana perubahan tertentu pada harga atau biaya akan mempengaruhi titik impas.

Ditinjau dari perkembangan suatu perusahaan yang semakin meningkat, maka dibutuhkan manajemen untuk menganalisa biaya produksi, volume penjualan, dan laba yang digunakan oleh perusahaan untuk mengadakan evaluasi kegiatan yang sudah berjalan maupun kegiatan yang akan datang. Oleh karena itu, diperlukan alat analisis yang dapat dijadikan pertimbangan manajemen dalam mengambil keputusan perusahaan agar terhindar dari kerugian. Analisis yang tepat untuk digunakan oleh pihak manajemen yaitu analisis biaya volume laba. Karena analisis ini merupakan teknik perencanaan laba jangka pendek atau suatu periode akuntansi tertentu yang dasar analisisnya pada variabilitas penghasilan penjualan maupun biaya terhadap volume kegiatan.

Analisis biaya volume laba merupakan salah satu alat analisis yang digunakan dalam pembuatan suatu perencanaan laba. Analisis tersebut akan menghasilkan nilai titik impas (break even point, BEP), nilai degree of operating leverage (DOL) dan nilai margin of safety (MOS). Analisis biaya volume laba akan memudahkan perusahaan dalam menentukan target pendapatan dan jumlah biaya yang dikeluarkan dalam upaya mencapai laba yang telah ditentukan tersebut (Ichsandy, 2018: 1).

Bagi perusahaan yang bergerak dalam industri makanan dan minuman, seperti Browcyl, penting dalam proses kemajuannya dengan tidak mengesampingkan analisis biaya volume laba dalam membantu perencanaan labanya setiap periode. Seperti yang telah ditelusuri oleh peneliti sebelumnya, Browcyl menjumpai berbagai hal yang menghambat pencapaian laba maksimal. Hal ini 
menyangkut biaya-biaya yang tidak sesuai dengan yang dianggarkan, sehingga berdampak pada kenaikan biaya bahan baku yang sebenarnya dapat dihindari apabila dengan perencanaan yang tepat.

Makassar merupakan kota yang memiliki potensi yang cukup besar, terutama jika kapasitas SDM (Sumber Daya Manusia) dikembangkan secara terarah dengan mendorong dan menanamkan jiwa enterpreneur kepada masyarakat yang dimulai sejak dini. Pertumbuhan ekonomi di Makassar yang sangat pesat ini ditandai dengan bermunculnya bisnis-bisnis baru disetiap tahunnya (Pratiwi, 2012). Ada beberapa perusahaan yang bergerak dalam bidang kuliner brownies di Kota Makassar, yang cukup besar dan terkenal yakni Brownies Amanda, ini merupakan hal yang wajar dikarenakan Brownies Amanda sudah begitu lama berdiri yakni dimulai sejak tahun 2000 (Rulita, 2011), Sehingga memiliki banyak konsumen.

Selain itu perusahaan lainnya yang bergerak dalam bidang kuliner brownies adalah Browcyl (Brownis Pisang Khas Makassar). Dibandingkan dengan Brownies Amanda, Browcyl lebih menarik untuk diteliti karena sejak usia tahun pertama berdiri, Browcyl telah berhasil memiliki tiga cabang di Kota Makassar. Terdapat dua cabang di wilayah Hertasning dan satu cabang di wilayah Pettarani. Di samping itu, nama Browcyl berhasil dikenal serta dapat bersaing dengan Brownies Amanda yang memang telah lama berdiri, yang lebih menariknya lagi Browcyl memiliki inovasi dengan menggabungkan Brownies dengan pisang dan mengusung sebuah brand dengan slogan Brownies Pisang Khas Makassar sebagai langkah atau strategi untuk menarik jumlah konsumen di Kota Makassar.

\section{TINJAUAN TEORITIK / LITERATURE REVIEW}

Cost mempunyai pengertian bahwa kita mempunyai sumber daya perusahaan yang terbatas dan untuk mendapatkannya diperlukan sejumlah pengorbanan atau pengeluaran tertentu. Semua saldo akun-akun dalam neraca adalah wujud daripada cost tersebut. Biaya yang akan memberikan manfaat (benefit) hanya pada periode berjalan/sekarang (current periode) biasanya dicatat sebagai beban (expense) dibandingkan aktiva. Beban/pengeluaran (expense) adalah pembelanjaan yang sekarang dikonsumsi atau biaya yang telah dihabiskan. Beban itu sendiri terjadi karena dua sebab, pertama yang berasal dari cost yang sudah expired (melampaui masanya) dan yang kedua karena penggunaan, maksudnya beban itu hadir jika sudah melakukan pemakaian tertentu atau utilitas. Misalnya: penggunaan air (PAM), listrik (PLN), telepon \& speedy (TELKOM), dst.

Menurut Mursyidi (2008: 13) mengemukakan "Biaya adalah pengorbanan sumber ekonomi baik yang berwujud maupun tidak berwujud yang dapat diukur dalam satuan uang, yang telah terjadi atau akan terjadi untuk mencapai tujuan tertentu." Bisa juga dikatakan bahwa biaya adalah pengorbanan yang dilakukan saat ini atau masa depan untuk mendapatkan manfaat tertentu dengan mengurangi kas atau harta sesuai ukuran satuan uang.

Menurut Dunia dan Wasilah (2009: 23) menjelaskan bahwa "klasifiksi biaya diperlukan untuk menyampaikan dan menyajikan data biaya agar berguna bagi manajemen dalam mencapai berbagai tujuannya". Sebelum memutuskan bagaimana menghimpun dan mengalokasikan biaya dengan baik, manajemen dapat melakukan pengklasifikasian biaya atas dasar: 1 . Objek biaya (Produk, Departemen); 2. Perilaku biaya; 3. Periode akuntansi; dan 4. Fungsi manajemen atau jenis kegiatan fungsional

Pengertian laba menurut Soemarso (2004: 227) "laba adalah merupakan selisih antara pendapatan danpengeluaran atau suatu kelebihan pendapatan yang diterima oleh perusahaansesudah dikurangi pengorbanan yang dikeluarkan, yang merupakan kenaikanbersih atas modal yang berasal dari kegiatan usaha". 
yaitu:

Menurut Tunggal (1995: 140) terdapat dua definisi dari pendapatan atau laba

1) Pendapatan operasi didefinisikan sebagai pendapatan operasi dikurangi semua biaya selain bunga (interest) dan pjaak penghasilan.

2) Laba bersih didefinisikan sebagai total pendapatan dikurangi semua biaya dan pengeluaran.

Sebelum memproduksi atau menghasilkan suatu produk, baik barang maupun jasa, perusahaan biasanya terlebih dahulu merencanakan seberapa besar laba yang ingin diperoleh. Penentuan besarnya laba yang ingin diperoleh merupakan prioritas utama bagi sebagian besar perusahaan, disamping hal-hal lainnya. Agar besarnya perolehan laba mudah ditentukan, maka salah satu caranya perusahaan harus mengetahui terlebih dahulu berapa titik impasnya. Artinya, perusahaan beroperasi pada jumlah produksi atau penjualan tertentu, sehingga perusahaan tidak mengalami kerugian ataupun keuntungan (Kasmir, 2010: 166-167).

Analisis titik impas atau analisis pulang pokok atau dikenal dengan nama analisis Break Even Point (BEP) merupakan salah satu analisi keuangan yang sangat penting dalam perencanaan keuangan perusahaan. Analisis titik impas sering juga disebut analisis perencanaan laba (profit planning). Analisis ini biasanya lebih sering digunakan apabila perusahaan ingin mengeluarkan suatu produk baru. Artinya, dalam memproduksi produk baru tentu berkaitan dengan masalh biaya yang haru dikeluarkan. Kemudian penentuan harga jual serta jumlah barang atau jasa yang akan diproduksi atau dijual ke konsumen, baik dalam unit maupun rupiah.

Salah satu kegiatan analisis titik impas adalah untuk mengetahui pada jumlah berapa hasil penjaualan sama dengan jumlah biaya. Atau perusahaan beroperasi dalam kondisi tidak laba dan tidak pula rugi, atau laba sama dengan nol. Melalui analisis titik impas kita akan dapat mengetahui bagaimana hubungan antara biaya tetap, biaya variabel, tingkat keuntungan yang diinginkan, dan volume kegiatan (penjualan atau produksi). Oleh karena itu, analisis ini juga sering disebut pula dengan nama cost profit volume analisis.

Menurut Samryn (2001: 168) titik impas merupakan tingkat aktivitas dimana suatu organisasi tidak mendapat laba dan juga tidak menderita rugi. Titik impas juga dapat didefinisikan sebagai titik di mana total pendapatan sama dengan total biaya atau sebagai titik dimana total margin kontribusi sama dengan total biaya tetap.

Analisis titik impas memberikan pedoman tentang berapa jumlah produk minimal yang haru diproduksi atau dijual. Tujuannya adalah ag ar perusahaan mampu memperoleh laba (keuntungan) yang maksimal. Artinya, dengan memproduksi sejumlah barang dengan kapasitas produksi yang dimilikinya perusahaan akan tahu batas minimal yang harus dijual dan keuntungan maksimal yang diperoleh apabila diproduksi secara penuh.

3) Titik impas ini selanjutnya dapat dihitung dengan menggunakan metode persamaan, metode marjin kontribusi, dan metode grafik. Baik dalam hitungan unit penjualan maupun penjualan dalam satuan mata uang tertentu yang digunakan dalam transaksi bisnis.

\section{METODE PENELITIAN / METHODS}

Metode pengumpulan data yang dilakukan peneliti ialah dengan Metode Penelitian Langsung (Field Research) yang meliputi tiga hal yakni:

Al-Kharaj: Journal of Islamic Economic and Business Vol. 1 No. 1, juni 2019 
Pengamatan yang dilakukan sesuai dengan objek dari penelitian, seperti jumlah pelanggan, pencatatan penerimaan dan pengeluaran yang dilakukan perusahaan, dan hal-hal lain yang mendukung.

Wawancara ditujukan kepada pihak-pihak yang secara langsung berpengaruh pada perusahaan seperti pimpinan atau manajer, maupun karyawan yang berkaitan dengan objek penelitian. Wawancara yang dilakukan berdasar pada kerangka-kerangka yang telah disusun oleh peneliti sebelumnya agar wawancara yang dilakukan efektif dan efisien.

Dokumentasi yang dimaksud ialah data-data yang dimiliki perusahaan yang memiliki relevansi dengan objek penelitian seperti Laporan Keuangan periode sebelumnya, Laporan Penjualan, dan data akuntansi lainnya.

Selain metode Penelitian Langsung (Field Research), penelitian juga dilakukan dengan metode Kepustakaan. Metode ini dilakukan dengan mempelajari berbagai literatur, buku, jurnal, dokumen, dan referensi lainnya yang berkaitan dengan objek penelitian.

Untuk mendukung berhasilnya penelitian, data penelitian yang diambil dan diolah adalah data fisik dan data dokumenter. Data fisik yang dimaksud ialah data yang terpampang nyata di lapangan. Sedangkan data dokumenter ialah hasil dari peristiwa yang telah terjadi dan didokumentasikan melalui pencatatan dan laporan keuangan pada periode sebelumnya. Adapun sumber data yang menjadi acuan penelitian ialah:

Data primer ialah data yang secara langsung diperoleh oleh peneliti, baik berupa data kualitatif melalui wawancara langsung selama masa penelitian terkait dengan latar belakang perusahaan, struktur organisasi, dan sebagainya, serta data kuantitatif yang memuat informasi kondisi keuangan perusahaan dalam laporan keuangan berupa biaya, volume, dan penjualan perusahaan.

Data sekunder ialah data yang yang telah dikumpulkan oleh peneliti melalui sumbersumber yang telah ada sebelumnya. Data ini dapat diperoleh melalui berbagai literatur, buku, jurnal yang relevan, dan lain sebagainya.

Tahapan-tahapan dalam menganalisis data yang akan diperoleh nantinya dari perusahaan ialah sebagai berikut:

Pengklasifikasian biaya berdasarkan prilakunya

Biaya diklasifikasikan berdasarkan prilaku dari biaya sehingga dapat diketahui biaya yang termasuk biaya tetap dan biaya variabel.

Menghitung analisis peramalan, target laba dan dasar-dasar analisis biaya volume laba dengan rumus dan formula,

\section{HASIL DAN PEMBAHASAN / DISCUSSION}

Titik impas dapat didefinisikan sebagai titik pada saat pendapatan penjualan cukup untuk menutup semua biaya produksi dan penjualan tetapi tidak ada laba yang diperoleh. Titik impas yang dimana perusahaan tidak mendapatakan keuntungan dan juga tidak mengalami kerugian. Titik impas yang dialami Browcyl Brownies Pisang Khas Makassar pada tahun 2017 dan 2018 yaitu pada tahun 2017 BEP dalam rupiah Browcyl Brownies Pisang Khas Makassar sebesar Rp. 72.070.308,51 dan BEP per kg sebesar Rp. 1.018 yang berarti bahwa pada tahun 2017, perusahaan mampu menutupi seluruh biaya tersebut untuk mencapai impas. Tahun 2018 BEP dalam rupiah Browcyl Brownies Pisang Khas Makassar sebesar Rp. 69.612.903,23 dan 
BEP per kg sebesar 2.308 yang berarti bahwa pada tahun 2018, perusahaan mampu menutupi seluruh biaya tersebut untuk mencapai impas.

Berdasarkan analisis di atas Browcyl Brownies Pisang Khas Makassar dapat mencapai titik impas walaupun di setiap tahunnya terjadi penaikan dan penurunan baik dalam segi jumlah penjualan dan volume biaya-biaya yang dikeluarkan perusahaan. Hal ini biasa dialami oleh perusahaan-perusahaan dimana terjadi naik turun penjualan dan persaingan dengan perusahaan-perusahaan lain yang sama jenis produk yang ditawar. Tetapi dalam hal ini perusahaan mampu menutup biaya-biaya tersebut.

Margin keamanan atau margin of safety adalah kelebihan dari penjualan yang dianggarkan diatas titik impas volume penjualan. Margin kemanaan menjelaskan jumlah dimana penjualan dapat menurun sebelum kerugian mulai terjadi. Besar margin of safetyatau batas keamanan agar jumlah penjualan Browcyl Brownies Pisang Khas Makassar boleh berkurang dari rencana semula sehingga perusahaan tidak menderita rugi.

Dari data BEP dan Contribution margin anggaran penjualan tahun 2017 dan 2018 maka diperoleh tingkat margin of safety pada tahun 2017 sebesar $83 \%$ yang berarti bahwa pada tingkat penjualan dan jumlah maksimum penurunan target pendapatan penjualan yang tidak menyebabkan perusahaan mengalami kerugian adalah Rp. 349.222.500. Margin of safety pada tahun 2018 sebesar $86 \%$ yang berarti bahwa pada tingkat penjualan dan jumlah maksimum penurunan target pendapatan penjualan yang tidak menyebabkan perusahaan mengalami kerugian adalah Rp. 426.542.800.

Analisis di atas menganalisis dan memperhitungkan batas keamanan jumlah penjualan yang boleh berkurang dari rencana semula sehingga perusahaan tidak menderita rugi. Margin keamanan ini didapat dari perhitungan persentase hasil penjualan dikurang titik impas. Dalam margin keamanan jika perusahaan mencapai titik margin keamanan maka perusahaan masih memperoleh keuntungan. Semakin tinggi margin of safety suatu perusahaan dikatakan semakin baik karena rentang penurunan penjualan yang dapat ditolerir adalah lebih besar sehingga kemungkinan menderita kerugian lebih rendah. Semakin kecil margin of safety berarti semakin cepat perusahaan menderita kerugian.

Untuk menentukan tingkat penjualan yang dibutuhkan agar mencapai tingkat laba yang diharapkan. Mencari laba yang diharapkan meliputi perencanaan pendapatan. Perencanaan pendapatan menentukan pendapatkan yang dibutuhkan agar mencapai tingkat laba yang diharapkan lebih terkendali. Penjualan tahun 2017 dan 2018 telah mencapai dari target penjualan yang telah dihitung maka perusahaan harus mengusahaakn penjualan tetap melebihi dari target yang telah ditentukan.

\section{PENUTUP}

Berdasarkan analisis data yang dilakukan pada Browcyl Brownies Pisang Khas Makassar maka dapat diambil kesimpulan sebagai berikut:

1. Dari hasil analisis yang dilakukan oleh peneliti bahwa perusahaan mampu mencapai titik impas atau mencukupi biaya-biaya pada tahun 2017 dan 2018. Titik impas ialah titik dimana total pendapatan sama dengan total biaya yang dikeluarkan perusahaan. Dimana pada tahun 2017 titik impas yang dicapai perusahaan sebesar Rp. 72.070.308,51 dan BEP per kg sebesar Rp. 1.018. Pada tahun 2018 titik impas yang dicapai perusahaan sebesar Rp. 69.612.903,23 dan BEP per kg sebesar 2.308 .

2. Margin of safety menunjukkan jarak antara penjualan yang direncanakan dengan penjualan pada break even. Dengan demikian margin of safety juga menggambarkan batas jarak, dimana kalau berkurangnya penjualan melapaui batas jarak tersebut perusahaan akan menderita kerugian. Browcyl Brownies Pisang Khas Makassar tahun 2017 ke tahun 2018 mengalami kenaikan 83\% menjadi $86 \%$. Semakin tinggi margin of safety suatu perusahaan dikatakan semakin baik karena

Al-Kharaj: Journal of Islamic Economic and Business Vol. 1 No. 1, juni 2019 
rentang penurunan penjualan yang dapat ditolerir adalah lebih besar sehingga kemungkinan menderita kerugian rendah. Semakin kecil margin of safety berarti semakin cepat perusahaan menderita kerugian, dalam hal ini terdapat penurunan jumlah penjualan yang nyata.

Penjualan tahun 2017 dan 2018 telah mencapai target penjualan yang telah dihitung, maka perusahaan harus mengusahakan kestabilan penjualan dari target yang telah ditentukan.

\section{KESIMPULAN / CONCLUSION}

Berdasarkan analisis data yang dilakukan pada Browcyl Brownies Pisang Khas Makassar maka dapat diambil kesimpulan sebagai berikut:

3. Dari hasil analisis yang dilakukan oleh peneliti bahwa perusahaan mampu mencapai titik impas atau mencukupi biaya-biaya pada tahun 2017 dan 2018. Titik impas ialah titik dimana total pendapatan sama dengan total biaya yang dikeluarkan perusahaan. Dimana pada tahun 2017 titik impas yang dicapai perusahaan sebesar Rp. 72.070.308,51 dan BEP per kg sebesar Rp. 1.018. Pada tahun 2018 titik impas yang dicapai perusahaan sebesar Rp. 69.612.903,23 dan BEP per kg sebesar 2.308.

4. Margin of safety menunjukkan jarak antara penjualan yang direncanakan dengan penjualan pada break even. Dengan demikian margin of safety juga menggambarkan batas jarak, dimana kalau berkurangnya penjualan melapaui batas jarak tersebut perusahaan akan menderita kerugian. Browcyl Brownies Pisang Khas Makassar tahun 2017 ke tahun 2018 mengalami kenaikan $83 \%$ menjadi $86 \%$. Semakin tinggi margin of safety suatu perusahaan dikatakan semakin baik karena rentang penurunan penjualan yang dapat ditolerir adalah lebih besar sehingga kemungkinan menderita kerugian rendah. Semakin kecil margin of safety berarti semakin cepat perusahaan menderita kerugian, dalam hal ini terdapat penurunan jumlah penjualan yang nyata.

Penjualan tahun 2017 dan 2018 telah mencapai target penjualan yang telah dihitung, maka perusahaan harus mengusahakan kestabilan penjualan dari target yang telah ditentukan.

\section{DAFTAR PUSTAKA / REFERENCES}

Ahmad, Kamaruddin. 2011. Akuntansi Manajemen. Jakarta: Raja Grafindo Persada, 2011. Armila, Warindrani, Krisna. 2006. Akuntansi Manajemen. Yogyakarta: Graha Ilmu. Astuti, Widia. 2014. Akuntansi Manajemen. Bandung: Citapustaka Media Perintis. Blocher, Edward J. 2011. Manajemen Biaya: Penekanan Strategis. Jakarta: Salemba Empat. Bustami, Bastian. dan Nurlela. 2006. Akuntansi Biaya Teori dan Aplikasi.Yogyakarta: Graha Ilmu.

Dahlia HB. 2011. "Analisis Cost-Volume-Provit (CVP) Sebagai Alat Bantu Perencanaan Laba PT. Pabrik Gula Takalar”. Skripsi. Makassar: Program Studi Akuntansi, Universitas Hasanuddin.

Dewi, Dian Ratna Rusmala. 2017. Analisis Hubungan Margin Kontribusi Sebagai Alat Bantu Perencanaan Laba Pada Industri Gamelan Margolaras Kauman Magetan periode 2014-2016. Madiun: Universitas PGRI Madiun, Vol. 5 No. 1, (2017).

Dunia, Firdaus A. dan Abdullah, Wasilah. 2009. Akuntansi Biaya. Edisi 2. Jakarta: Salemba Empat

Endhonanta, Ariek. 2013. "Analisis Biaya-Volume-Laba Sebagai Alat Perencanaan Laba pada UD. Hatono Putra Balung Jember”. Skripsi. Jawa Timur: Program Studi Manajemen, Universitas Jember. 
Garrison, Ray H., Noreen, Eric W., and Brewer, Peter C. 2000. Managerial Accounting. Fourteenth Edition. Diterjemahkan oleh Kartika Dewi. Jakarta: Salemba Empat.

Halim, Mamduh M Hanafidan Abdul. 2006. Analisis Laporan Keuangan. Yogyakarta: Unit Penerbitan dan Percetakan AMP-YKPN.

Hansen, Don R., and Mowen, Marryanne M. 2011. Managerial Accounting. Eighth Edition.

Diterjemahkan oleh Denny Arnos Kwary. Jakarta: Salemba Empat

Hansen, Don R., and Mowen, Marryanne M. 2011. Managerial Accounting. Eighth Edition.

Diterjemahkan oleh Denny Arnos Kwary. Jakarta: Salemba Empat

Harahap, Sofyan Syafri. 2013. Teori Akuntansi. Jakarta: Rajawali Pers.

Hery. 2009. Teory Akuntansi. Jakarta: Kencana Prenada Media Group.

Ichsandy, Muhammad. 2018. "Analisis Biaya Volume Laba Sebagai Alat Perencanaan Laba

Ikhsan, Arfan. 2016. Analisa Laporan Keuangan. Medan: Madenatera.

Kasmir. 2010. Pengantar Manajemen Keuangan. Jakarta: Kencana Prenada Media Group. 2011. Analisis Laporan Keuangan. Jakarta: Raja Grafindo Persada.

Matz, Adolph. 1992. Akuntansi Biaya Perencanaan dan Pengendalian. Jakarta: Erlangga.

Munawaroh, Sofiatul. 2016. "Analisis Biaya Volume Laba Sebagai Alat Perencanaan Laba

Pada Ud. Mentari Pasuruan”. Skripsi. Malang: Fakultas Ekonomi Universitas Islam Negeri Maulana Malik Ibrahim Malang.

Mursyidi. 2008. Akuntansi Biaya Conventional Costing, Just In Time, dan Activity Based Costing. Bandung: PT Refika Aditama.

Pada PT. Perkebunan Nusantara III (Persero) Medan". Skripsi. Medan: Fakultas Ekonomi dan Bisnis Universitas Muhammadiyah Sumatera Utara Medan

Prastowo, Dwi dan Rifka Julianty. 2007. Analisis Laporan Keuangan. Yogyakarta: Akademi Manajemen Perusahaan YKPN.

Pratiwi, Gustyanita. 2012. "Makassar Siap Menjadi Global Business City" 03 September 2012, http:// swa.co.id/business-strategy/management/Makassar-siap-menjadi-globalbusiness-city (21 Mei 2019.

Raiborn, Cecily A. dan Michael R. Kinney. 2011. Akuntansi Biaya Dasar dan Perkembangan. Jakarta: Salemba Empat

Rangkuti, Freddy. 2009. Strategi Promosi yang Kreatif dan Analisis Kasus Integrated Marketing Communication. Bogor: Grafika Mardi Yuana.

Rulita, Bebbie. 2011. "Analisis Faktor yang Mempengaruhi Konsumen dalam Memutuskan Pembelian Produk Brownis Amanda". Skripsi. Medan: Universitas Sumatra Utara.

Salvatore, Dominick. 2005. Managerial Economics in A Global Economy. Fifth Edition. Diterjemahkan oleh Ichsan Setyo Budi. Jakarta: Salemba Empat.

Samryn. 2001. Akuntansi Manajerial Suatu Pengantar. Jakarta: PT Raja Grafindo Persada. Carter, William K. 2009. Cost Accounting. Fourteenth Edition. Diterjemahkan oleh Krista. Jakarta: Salemba Empat.

Sihombing, Selfinta B. 2013. "Analisis Biaya Volume Laba Sebagai Alat Bantu Perencanaan Laba PT. Bangun Wenang Beverages Company". Jurnal Ilmiah. Manado: Program Studi Akuntansi, Universitas Sam Ratulangi.

Simamora, Henry. 2012. Akuntansi Manajemen. Edisi III. Duri: Star Gate Publisher. Sjahrial, Dermawan, dan Djahotman Purba. 2012. Akuntansi Manajemen. Bogor: Mitra Wacana Media.

Soemarso S.R. 2004. Akuntansi Suatu Pengantar. Buku 2, Edisi 5. Jakarta: Salemba Empat. Mulyadi. 2005. Akuntansi Biaya, Edisi Kelima. Cetakan Ketujuh. Yogyakarta: Akademi Manajemen Perusahaan YKPN.

Al-Kharaj: Journal of Islamic Economic and Business Vol. 1 No. 1, juni 2019 
Sujarweni, V Wiratna. 2014. Metodologi Penelitian. Cetakan Pertama. Yogyakarta: Pustaka Baru Press.

The, Ishak., dan Sugiono, Arief. 2015. Akuntansi Informasi dalam Pengambilan Keputusan. Jakarta: PT. Grasindo.

Tjiptono, Fandy dan Gregorius Chandra. 2012. Pemasaran Strategik: Mengupas Pemasaran Strategik, Branding Strategy, Customer Satisfaction, Strategi Kompetitif, hingga eMarketing. Yogyakarta: Penerbit Andi.

Verawati, Eti. 2014. "Penerapan Metode CVP (Cost-Volume-Profit) Sebagai Alat Bantu Analisis Perencanaan Laba dalam Mencapai Target Perusahaan pada UKM Vinito Brownis”. Jurnal. Program Studi Akuntansi. Semarang: Universitas Dian Nuswantoro.

Wiharjo, Nelly. 2011. "Analisis Cost-Volume-Provit (CVP) untuk Perencanaan Laba pada Hotel Losari Beach”. Skripsi. Makassar: Program Studi Akuntansi, Universitas Hasanuddin. 